O $\quad$ R I I G I

$\begin{array}{llllllll}A & R & T & \text { I } & C & \text { L } & \text { E }\end{array}$

\title{
The role of high-sensitivity C-reactive protein for assessing coronary artery disease severity and left ventricular end diastolic pressure in patients with suspected coronary artery disease
}

\author{
H Rashidinejad \\ A Rashidinejad \\ M Moazenzadeh \\ BS Azimzadeh \\ RM Afshar \\ A Shahesmaeili \\ F Mirzaeepour
}

Key words

Coronary artery disease; C-reactive protein; Heart ventricles

Hong Kong Med J 2013;19:328-33 DOI: $10.12809 / \mathrm{hkmj} 133601$

Physiology Research Center, Kerman University of Medical Sciences, Kerman,

H Rashidinejad, A Rashidinejad, MD M Moazenzadeh, MD BS Azimzadeh, MD RM Afshar, MD A Shahesmaeili, MD

F Mirzaeepour, MD

Correspondence to: Dr H Rashidinejad Email: hrashidinejad@yahoo.com
Objective Much attention has recently been focused on the underlying role of circulating inflammatory biomarkers such as high-sensitivity C-reactive protein for predicting cardiovascular disease progression. We therefore set out to assess the relationship between the value of high-sensitivity C-reactive protein and (i) coronary artery disease severity, and (ii) left ventricular end diastolic pressure.

Design A cross-sectional study.

Setting The Shafa hospital in Kerman, Iran.

Patients A total of 107 consecutive patients referred for coronary angiography from January 2008 to January 2009 were prospectively studied.

Intervention and All patients underwent coronary angiography. They all had main outcome measures undergone left ventricular end diastolic pressure measurement, involving a 6-Fr pigtail catheter and a properly zeroed fluid-filled pressure transducer. For each patient, the level of high-sensitivity C-reactive protein was also determined using enzyme-linked immunosorbent assay kits.

Results The high-sensitivity C-reactive protein levels could strongly predict increased left ventricular end diastolic pressure (standardised beta=1.010; $\mathrm{P}=\mathbf{0 . 0 0 8}$ ), with other patient variables being confounders, but there was no significant association between these levels and Gensini scores. Multiple linear regression analysis showed that among the study parameters, systolic hypertension (standardised beta=1.611; $\mathrm{P}=0.047$ ) and a family history of coronary artery disease (standardised beta=1.911; $P=0.005$ ) were the main predictors of high Gensini scores in study patients.

Conclusion High-sensitivity C-reactive protein level is a clinical parameter that could predict left ventricular end diastolic pressure and left ventricular dysfunction, but was not associated with the severity of coronary artery disease.
New knowledge added by this study

- The current study could demonstrate the role of assessing high-sensitivity C-reactive protein for predicting left ventricular end diastolic pressure and left ventricular dysfunction in coronary artery disease patients.

\section{Implications for clinical practice or policy}

- Because of confirmed potential role of inflammatory processes in ischaemic heart disease, high-sensitivity C-reactive protein can be applied diagnostically as a main indicator for assessment of inflammatory sources in coronary artery disease patients.

\section{Introduction}

Recently, attention has been focused on the role of the circulating inflammatory biomarkers such as C-reactive protein (CRP) for predicting cardiovascular disease progression. ${ }^{1} \mathrm{~A}$ wide variety of clinical investigations in healthy as well as high-risk individuals have shown a relationship between this biomarker and the risk of coronary artery disease (CAD) and its 
related life-threatening events. ${ }^{2-6}$ Some investigators hypothesised that irrespective of the extent and severity of CAD, serum CRP level is an index of atheromatous plaque activity and vulnerability. ${ }^{7}$ In addition, a high normal CRP level might be a reliable marker of cardiovascular risk even if its level is within the physiological range.,9 Some researchers have therefore used this parameter to screen patients at risk of developing clinically symptomatic CAD, though some authorities considered this approach to be premature. ${ }^{10}$ Besides, as shown by the increment in CRP values, the immune system is frequently activated in patients with the chronic left ventricular dysfunction. ${ }^{11}$ However, results from a study of American patients with ischaemic heart disease and left ventricular systolic dysfunction undergoing coronary angiography suggested that those with an elevated high-sensitivity CRP (hs-CRP) had a worse prognosis. ${ }^{12}$ A study of the Japanese patients with dilated cardiomyopathy also yielded similar findings. ${ }^{13}$

To date, few studies have examined the relationship between systemic markers of inflammation such as hs-CRP and regional left ventricular dysfunction and its parameters. We therefore set out to assess the value of measuring hs-CRP to determine whether the prevailing level was related to CAD severity and the left ventricular end diastolic pressure (LVEDP).

\section{Methods}

We measured the plasma hs-CRP levels in 107 consecutive patients (mean \pm standard deviation [SD] age: $55 \pm 8$ years, range: $40-85$ years); of these, 78 were males. They all underwent elective coronary angiography for suspected CAD at the Shafa hospital in Kerman, Iran from January 2008 to January 2009. This is a referral hospital for Kerman Province, Iran. The results were compared with the coronary angiography findings. None of these patients had experienced myocardial infarction (MI) within the last 6 months, or unstable angina with anginal pain at rest within 1 month, nor had they undergone a percutaneous coronary intervention or coronary artery bypass within 12 months before assessment. None of the patients had congestive heart failure, life-threatening arrhythmias, renal or liver diseases, or malignancies, nor had they endured any infectious or inflammatory disorders within the last 2 weeks. At the time of diagnostic angiography, clinical data were collected on all the patients, including age, gender, and coronary risk factors. Relevant risk factors were current smoking history (ie regularly smoked once or more daily or smoked in the 30 days prior to admission), ${ }^{14}$ presence of hypercholesterolaemia (total cholesterol of $\geq 5.0 \mathrm{mmol} / \mathrm{L}$, high-density lipoprotein-cholesterol of $\leq 1.0 \mathrm{mmol} / \mathrm{L}$ in male /

\section{高敏C反應蛋白在評估懷疑冠心病患者中其 冠心病嚴重程度和左室舒張末壓的角色}

目的炎症生物標記物, 例如高敏 C反應蛋白, 對預測心血 管病進度的基本作用倍受關注。因此, 本文評估高敏 C反應蛋白和以下兩者的關係：（1）冠狀動脈病嚴重 程度和 (2) 左室舒張末壓。

設計 橫斷面研究。

安排 伊朗克爾曼Shafa醫院。

患者 納入 2008 年1月到2009年1月期間, 所有 107 名轉介至 冠狀血管學的患者進行前瞻性研究。

干預及主要 所有患者接受冠狀動脈造影檢查, 並以6-Fr猪尾型導 結果測量 管和已調整的充液壓力傳感器量度他們的左室舒張末 壓。研究並使用ELIZA工具檢視每名患者的高敏C反 應蛋白水平。

結果 當其他患者變數是共同物時, 高敏 $\mathrm{C}$ 反應蛋白水平能 強烈預測左室舒張末壓上升（標準化beta值 $=1.010$; $\mathrm{P}=0.008 ） ，$ 但這些數值水平與冠脈評分間沒有顯著 相關。多線性回歸分析顯示在多個研究參量中, 收縮 期高血壓（標準化beta值 $=1.611 ; \mathrm{P}=0.047$ ) 和冠狀 動脈病家族史（標準化beta值 $=1.911 ; \mathrm{P}=0.005)$ 是 患者高冠脈評分的主要預測因子。

結論 高敏 $\mathrm{C} 反$ 應蛋白水平是可預測左室舒張末壓和左心室 功能異常的臨床參量, 但其與冠心病嚴重程度並無顯 著相關。 $\leq 1.1 \mathrm{mmol} / \mathrm{L}$ in female, and triglycerides of $\geq 2.0$ $\mathrm{mmol} / \mathrm{L}){ }^{15}$ a family history of CAD (first-degree relatives; men aged $<55$ years and women $<65$ years), ${ }^{16}$ hypertension (systolic blood pressure of $\geq 140 \mathrm{~mm}$ $\mathrm{Hg}$ and/or diastolic pressure of $\geq 90 \mathrm{~mm} \mathrm{Hg}$ and/ or on antihypertensive treatment), ${ }^{17}$ and diabetes mellitus (symptoms of diabetes plus at least one of the following: plasma glucose concentration of $\geq 11.1$ $\mathrm{mmol} / \mathrm{L}$, fasting plasma glucose of $\geq 7.0 \mathrm{mmol} / \mathrm{L}$, and 2-hour postprandial plasma glucose $\geq 11.1 \mathrm{mmol} / \mathrm{L}$ ). ${ }^{18}$

The entire study protocol was approved by the ethics committee of the Kerman University of Medical Sciences, and written informed consent was obtained from the patients. Blood samples were taken from the patients for laboratory testing within 24 hours of hospital admission. Blood obtained from the coronary sinus was collected in EDTA bottles for CRP measurement. The samples were centrifuged (3000 revolutions/min at $4^{\circ} \mathrm{C}$ for 15 minutes) and the plasma separated. The hs-CRP level was determined using a commercial enzyme-linked immunosorbent assay kits (Monobind, US).

All coronary angiography procedures were performed via the femoral approach using the standard Judikin's technique, and the images were 
analysed separately by two independent investigators. For each patient, the mean reported Gensini score from the two blinded cardiologists were used. Images of the coronary tree were obtained in routine standardised projections with the digital Integris H3000 System (Siemens, Germany). Any significant lesions ( $>50 \%$ stenosis) in the left main coronary artery (LM), left anterior descending coronary artery (LAD), left circumflex coronary artery (LCX), and right coronary artery (RCA) were recorded, in which case patients were classified as having 1-vessel, 2-vessel, or 3-vessel disease. The Gensini scoring system was utilised in the evaluation of coronary lesion severity. The Gensini score for each patient was inferred from the coronary arteriogram by assigning a severity score to each coronary stenosis according to the degree of luminal narrowing and its geographical importance. Reduction in the lumen diameter, and the roentgenographic appearance of concentric lesions and eccentric plaques were evaluated; reductions of $25 \%, 50 \%, 75 \%, 90 \%, 99 \%$, and complete occlusion were given scores of 1, 2, 4, 8, 16, and 32, respectively. Each principal vascular segment was assigned a multiplier in accordance with the functional significance of the myocardial area supplied by that segment: $L M \times 5$; the proximal segment of $L A D \times 2.5$; the proximal segment of LCX $\times 2.5$; the mid-segment of the LAD $\times 1.5$; the RCA, the distal segment of the LAD, the posterolateral artery and the obtuse marginal artery $\times 1$; and others $\times 0.5 .{ }^{19}$ All patients underwent recording of their LVEDP using a 6 -Fr pigtail catheter and a properly zeroed fluid-filled pressure transducer. The pressure was recorded using a $50 \mathrm{~mm} \mathrm{Hg}$ scale at $50 \mathrm{~mm} / \mathrm{s}$ paper speed. A blinded physician measured the post-A wave LVEDP based on a minimum of five consecutive cardiac cycles.

Results were reported as mean \pm SD for quantitative variables and percentages for the categorical variables. Continuous variables (Gensini score and LVEDP) in different risk subgroups were compared using the Student's $t$ test or the MannWhitney $U$ test. Multiple linear regression analysis was used to investigate the association between hs-CRP and these two variables in the presence of baseline data as confounders. Standardised beta was calculated. Any P value of $<0.05$ was considered statistically significant. All the statistical analyses were performed using the SPSS version 13.0 (SPSS Inc., Chicago [IL], US) and SAS version 9.1 for Windows (SAS Institute Inc., Cary [NC], US).

\section{Results}

The baseline characteristics of the study subjects are summarised in Table 1 . The most frequent risk factor for CAD was hypercholesterolaemia (48\%) followed by opium addiction (44\%) and systolic hypertension $(37 \%)$. The mean LVEDP in different
TABLE I. Baseline demographic and clinical data of study patients $(n=107)$

\begin{tabular}{lc}
\hline Characteristic $^{*}$ & Data $^{\dagger}$ \\
\hline Male gender & $78(73)$ \\
\hline Age (years) & $55 \pm 8$ \\
\hline Diabetes mellitus & $23(21)$ \\
\hline Systolic hypertension & $40(37)$ \\
\hline Diastolic hypertension & $12(11)$ \\
\hline Hypercholesterolaemia & $51(48)$ \\
\hline Hypertriglyceridaemia & $41(38)$ \\
\hline Total cholesterol to HDL ratio of $>4$ & $48(45)$ \\
\hline Family history of coronary disease & $31(29)$ \\
\hline Current smoking & $31(29)$ \\
\hline Opium addiction & $47(44)$ \\
\hline Gensini score & $42.4 \pm 36.2$ \\
\hline High-sensitivity C-reactive protein & $16.1 \pm 7.1$ \\
\hline LV end diastolic pressure (mm Hg) & $8.6 \pm 13.5$ \\
\hline * HDL denotes high-density lipoprotein, and LV left ventricular \\
\hline Data are shown as mean \pm standard deviation or No. (\%) of \\
\hline patients
\end{tabular}

TABLE 2. Left ventricular end diastolic pressure (LVEDP) measurement and Gensini score in different risk factors subgroups*

\begin{tabular}{lcc}
\hline Item & LVEDP & Gensini score \\
\hline Male & $16.2 \pm 2.2$ & $43.3 \pm 1.3$ \\
\hline Female & $16.5 \pm 1.8$ & $45.2 \pm 0.9$ \\
\hline P value & 0.493 & $<0.001$ \\
\hline With diabetes & $16.2 \pm 1.5$ & $45.4 \pm 1.2$ \\
\hline Without diabetes & $16.4 \pm 1.3$ & $42.2 \pm 1.2$ \\
\hline \multicolumn{1}{|c}{ P value } & 0.578 & $<0.001$ \\
\hline With systolic hypertension & $16.5 \pm 1.1$ & $47.2 \pm 1.5$ \\
\hline Without systolic hypertension & $16.2 \pm 1.2$ & $40.4 \pm 1.1$ \\
\hline P value & 0.147 & $<0.001$ \\
\hline With hyperlipidaemia & $15.8 \pm 1.1$ & $49.7 \pm 1.6$ \\
\hline Without hyperlipidaemia & $16.7 \pm 1.2$ & $38.8 \pm 1.1$ \\
\hline P value & $<0.001$ & $<0.001$ \\
\hline With a family history of CAD ${ }^{\dagger}$ & $17.8 \pm 2.0$ & $51.6 \pm 1.8$ \\
\hline Without a family history of CAD & $15.5 \pm 1.8$ & $17.8 \pm 0.3$ \\
\hline P value & $<0.001$ & $<0.001$ \\
\hline With cigarette smoking & $16.9 \pm 1.2$ & $45.9 \pm 1.2$ \\
\hline Without cigarette smoking & $16.0 \pm 1.1$ & $44.1 \pm 1.2$ \\
\hline P value & $<0.001$ & $<0.001$ \\
\hline With opium use & $16.9 \pm 1.2$ & $51.2 \pm 2.3$ \\
\hline Without opium use & $15.6 \pm 1.3$ & $39.0 \pm 1.1$ \\
\hline P value & $<0.001$ & $<0.001$ \\
\hline
\end{tabular}

* Data are presented as mean \pm standard deviation; data were analysed by $t$ tests

CAD denotes coronary artery disease 
risk subgroups (Table 2) was similar in patients with and without many of the study risk factors/profiles (gender, diabetes mellitus, and hypertension), while it was significantly higher in those without hyperlipidaemia, with a family history of CAD, history of smoking, or opium use than in those without. With respect to the differences in Gensini scores in different risk subgroups, subjects with at least one of these risk factors had higher scores. As shown in Table 3, hs-CRP measurement could strongly predict increased LVEDP (standardised beta $=1.010 ; \mathrm{P}=0.008$ ) in the presence of other variables as confounders. Multiple linear regression analysis also showed that among study parameters, systolic hypertension (standardised beta $=1.611 ; \mathrm{P}=0.047$ ) and a family history of CAD (standardised beta $=1.911 ; \mathrm{P}=0.005$ ) were main predictors of high Gensini score (Table 4). However, hs-CRP level had no significant association with Gensini score.

\section{Discussion}

Despite confirmed relationship between the levels of circulating inflammatory biomarkers and coronary atherosclerosis and its related life-threatening events in some previous studies, ${ }^{20-25}$ we could not demonstrate this association. In current study, hs-CRP concentrations were similar in patients with suspected $\mathrm{CAD}$ and did not correlate with the index of Gensini in these patients. Thus, serum CRP might not be a main predictor of disease activity; such findings are similar to others. For example, Veselka et $\mathrm{al}^{26}$ reported that the CRP level was not related to the extent of coronary atherosclerosis assessed by coronary angiography, a history of $\mathrm{Ml}$ or stable angina, in patients referred for coronary angiography or abnormal exercise test results. Another study ${ }^{27}$ also did not show a correlation between CRP and the extent of CAD. However, their study defined coronary atherosclerosis by a scoring system incorporating nine coronary artery segments. Interestingly, Hunt et $\mathrm{a}^{28}$ confirmed by electronbeam computed tomography that of those generally known risk factors of atherosclerosis, only low-density lipoprotein-cholesterol, and not CRP, was related to the extent of coronary calcifications. It therefore seems that the purported relationship between inflammatory biomarkers and the appearance or progression of coronary atherosclerosis might be spurious, possibly due to small-sample-size studies, methodology, or technical details for measuring these markers, and lack of control subjects without CAD. Thus, this association should be re-evaluated in further prospective cohort studies with larger sample sizes, and preferably in CAD patients and suitable controls.

Other studies noted that CRP levels were higher in patients with left ventricular dysfunction than that in the healthy population, and our study also found that hs-CRP was strongly predictive of increased LVEDP. Other multivariate analyses have also explored the presence of underlying risk profiles and elevated CRP levels. ${ }^{29,30}$

After adjustment for potential confounders, we demonstrated an independent association between hs-CRP and elevated left ventricular filling pressures as opposed to systolic or diastolic dysfunction. This finding indicates that CRP elevation is closely related to the overall syndrome of left ventricular dysfunction and volume overload. Similarly, Huang et $\mathrm{al}^{31}$ reported a modest statistically significant correlation coefficient of 0.26 between LVEDP and CRP; however, this was only associated with those with heart failure. Thus, it seems probable that elevations in CRP lead to increases in left ventricular filling pressures that progress to acute heart failure, or vice versa. In this context, assessment of changes in all left ventricular parameters following progression of inflammatory processing (in both animal and

TABLE 3. Linear regression model indicating relationship between the left ventricular end diastolic pressure and other study parameters*

\begin{tabular}{lcccc}
\hline Variable $^{\dagger}$ & Beta & P value & Standardised beta & P value \\
\hline hs-CRP & 1.008 & 0.009 & 1.010 & 0.008 \\
Male gender & 1.020 & 0.848 & 1.090 & 0.509 \\
Age & 1.112 & 0.222 & 1.150 & 0.257 \\
Diabetes mellitus & 1.002 & 0.989 & 1.117 & 0.380 \\
Systolic hypertension & 1.284 & 0.787 & 1.002 & 0.987 \\
Hyperlipidaemia & 1.033 & 0.666 & 1.014 & 0.899 \\
Family history of CAD & 1.071 & 0.444 & 1.078 & 0.471 \\
Current smoking & 1.051 & 0.611 & 1.132 & 0.287 \\
\hline Opium addiction & 1.084 & 0.356 & 1.198 & 0.111 \\
\hline
\end{tabular}

* $\mathrm{R}^{2}=0.761$

hs-CRP denotes high-sensitivity C-reactive protein, and CAD coronary artery disease

TABLE 4. Linear regression model indicating relationship between Gensini score and other study parameters*

\begin{tabular}{lcccc}
\hline Variable $^{\dagger}$ & Beta & P value & Standardised beta & P value \\
\hline hs-CRP & 1.001 & 0.974 & 1.006 & 0.477 \\
Male gender & 1.132 & 0.555 & 1.400 & 0.225 \\
Age & 1.006 & 0.602 & 1.001 & 0.922 \\
Diabetes mellitus & 1.087 & 0.724 & 1.044 & 0.866 \\
Systolic hypertension & 1.444 & 0.050 & 1.611 & 0.047 \\
Hyperlipidaemia & 1.299 & 0.192 & 1.445 & 0.091 \\
Family history of CAD & 1.824 & 0.005 & 1.911 & 0.005 \\
\hline Current smoking & 1.118 & 0.601 & 1.034 & 0.888 \\
\hline Opium addiction & 1.325 & 0.154 & 1.398 & 0.151 \\
\hline
\end{tabular}

$\mathrm{R}^{2}=0.658$

hs-CRP denotes high-sensitivity C-reactive protein, and CAD coronary artery disease 
humans) is recommended.

Limitations of this study included its crosssectional design and small sample size, which could potentially affect extrapolation of the data to predict future angiographic parameters and CAD severity. Moreover, other putative factors that could affect the predictive power of hs-CRP (eg nutritional status and physical activity) were not included in the regression analyses.

\section{Conclusion}

Our study attempted to explore the relationship of hs-CRP level with the CVD progression and left ventricular function. We could only demonstrate its role for predicting increased LVEDP and left ventricular dysfunction.

\section{Acknowledgement}

This study was supported by the Kerman University of Medical Sciences, Iran. We thank the University authorities who offered critical administrative support and managerial services in carrying out the study and also all other researchers for their help and support.

\section{References}

1. Hatmi ZN, Saeid AK, Broumand MA, Khoshkar SN, Danesh ZF. Multiple inflammatory prognostic factors in acute coronary syndromes: a prospective inception cohort study. Acta Med Iran 2010;48:51-7.

2. Harutyunyan MJ, Mathiasen $A B$, Winkel $P$, et al. Highsensitivity $\mathrm{C}$-reactive protein and $\mathrm{N}$-terminal pro-B-type natriuretic peptide in patients with stable coronary artery disease: a prognostic study within the CLARICOR Trial. Scand J Clin Lab Invest 2011;71:52-62. cross ref

3. Kincl V, Panovsky R, Meluzin J, et al. Association between laboratory markers and presence of coronary artery disease. Biomed Pap Med Fac Univ Palacky Olomouc Czech Repub 2010;154:227-33. cross ref

4. He P, Xie XH, Ding YP, Chen XL. Correlation between high sensitive C-reactive protein, lipoprotein(a), blood uric acid and severity of coronary artery disease [in Chinese]. Zhonghua Yi Xue Za Zhi 2010;90:1989-91.

5. Garcia-Moll X, Zouridakis E, Cole D, Kaski JC. C-reactive protein in patients with chronic stable angina: differences in baseline serum concentration between women and men. Eur Heart J 2000;21:1598-606. cross ref

6. Kiechl S, Egger G, Mayer M, et al. Chronic infections and the risk of carotid atherosclerosis: prospective results from a large population study. Circulation 2001;103:106470. cross ref

7. Arroyo-Espliguero R, Avanzas P, Cosín-Sales J, Aldama G, Pizzi C, Kaski JC. C-reactive protein elevation and disease activity in patients with coronary artery disease. Eur Heart J 2004;25:401-8. cross ref

8. Mendall MA, Strachan DP, Butland BK, et al. C-reactive protein: relation to total mortality, cardiovascular mortality and cardiovascular risk factors in men. Eur Heart J 2000;21:1584-90. cross ref

9. Ridker PM, Rifai A, Clearfield M, et al. Measurement of C-reactive protein for the targeting of statin therapy in the primary prevention of acute coronary events. N Engl J Med 2001;344:1959-65. cross ref

10. Krause KJ. C-reactive protein-a screening test for coronary disease? J Insur Med 2001;33:4-11.

11. Anzulović-Mirosević D, Razzolini R, Zaninotto M, et al. The C-reactive protein levels in left ventricular dysfunction of different etiology. Inflam Allergy Drug Targets 2009;8:24751. cross ref
12. Chirinos JA, Zamrano JP, Chakko S, et al. Usefulness of C-reactive protein as an independent predictor of death in patients with ischemic cardiomyopathy. Am J Cardiol 2005;95:88-90. cross ref

13. Kaneko K, Kanda T, Yamauchi Y, et al. C-reactive protein in dilated cardiomyopathy. Cardiology 1999;91:215-9. cross ref

14. Barrett-Connor E, Giardina EG, Gitt AK, Gudat U, Steinberg HO, Tschoepe D. Women and heart disease: the role of diabetes and hyperglycemia. Arch Intern Med 2004;164:934-42. cross ref

15. Wood D, De Backer G, Faergeman O, Graham I, Mancia G, Pyörälä K. Prevention of coronary heart disease in clinical practice. Recommendations of the Second Joint Task Force of European and other Societies on coronary prevention. Eur Heart J 1998;19:1434-503. cross ref

16. Bartnik M, Rydén L, Ferrari R, et al. The prevalence of abnormal glucose regulation in patients with CAD across Europe. The Euro Heart Survey on diabetes and the heart. Eur Heart J 2004;25:1880-90. cross ref

17. Chalmers J, MacMahon S, Mancia G, et al. 1999 World Health Organization-International Society of Hypertension Guidelines for the management of hypertension. Guidelines sub-committee of the World Health Organization. Clin Exp Hypertens 1999;21:1009-60. cross ref

18. American Diabetes Association. Diagnosis and classification of diabetes mellitus. Diabetes Care 2008;31(Suppl 1):S5560. cross ref

19. Gensini GG. A more meaningful scoring system for determining the severity of coronary heart disease. Am J Cardiol 1983;51:606. cross ref

20. Uydu HA, Bostan M, Yilmaz A, et al. Comparison of inflammatory biomarkers for detection of coronary stenosis in patients with stable coronary artery disease. Eur Rev Med Pharmacol Sci 2013;17:112-8.

21. Ridker PM, Cushman M, Stampfer MJ, Tracy RP, Hennekens $\mathrm{CH}$. Inflammation, aspirin, and the risk of cardiovascular disease in apparently healthy men. $N$ Engl J Med 1997;336:973-9. cross ref

22. Ridker PM, Buring JE, Shih J, Matias M, Hennekens $\mathrm{CH}$. Prospective study of $\mathrm{C}$-reactive protein and the risk of future cardiovascular events among apparently healthy women. Circulation 1998;98:731-3. cross ref

23. Liuzzo G, Biasucci LM, Gallimore JR, et al. The prognostic 
value of C-reactive protein and serum amyloid a proteinin severe unstable angina. N Engl J Med 1994;331:41724. cross ref

24. Haverkate F, Thompson SG, Pyke SD, Gallimore JR, Pepys $\mathrm{MB}$. Production of $\mathrm{C}$-reactive protein and risk of coronary events in stable and unstable angina. European Concerted Action on Thrombosis and Disabilities Angina Pectoris Study Group. Lancet 1997;349:462-6. cross ref

25. Zebrack JS, Muhlestein JB, Horne BD, Anderson JL, Intermountain Heart Collaboration Study Group. Creactive protein and angiographic coronary artery disease: independent and additive predictors of risk in subjects with angina. J Am Coll Cardiol 2002;39:632-7. cross ref

26. Veselka J, Procházková S, Duchonová R, et al. Relationship of C-reactive protein to presence and severity of coronary atherosclerosis in patients with stable angina pectoris or a pathological exercise test. Coron Artery Dis 2002;13:1514. cross ref

27. Azar RR, Aoun G, Fram DB, Waters DD, Wu AH, Kiernan FJ. Relation of C-reactive protein to extent and severity of coronary narrowing in patients with stable angina pectoris or abnormal exercise tests. Am J Cardiol 2000;86:2057. cross ref

28. Hunt ME, O'Malley PG, Vernalis MN, Feuerstein IM, Taylor A. C-reactive protein is not associated with the presence or extent of calcified subclinical atherosclerosis. Am Heart J 2001;141:206-10. cross ref

29. Targher G, Bertolini L, Zoppini G, Zenari L, Falezza G. Increased plasma markers of inflammation and endothelial dysfunction and their association with microvascular complications in Type 1 diabetic patients without clinically manifest macroangiopathy. Diabet Med 2005;22:9991004. cross ref

30. McLaughlin T, Abbasi F, Lamendola C, et al. Differentiation between obesity and insulin resistance in the association with C-reactive protein. Circulation 2002;106:290812. cross ref

31. Huang WP, Yin $W H$, Jen $H L$, Chiang MC, Feng AN, Young MS. C-reactive protein levels in chronic congestive heart failure. Acta Cardiol Sin 2004;20:7-14. 